\title{
Correction to: Picking 'Low-Hanging Fruit' While the Orchard Burns: the Costs of Policing Humanitarian Actors in Italy and Greece as a Strategy to Prevent Migrant Smuggling
}

\author{
Jennifer Allsopp ${ }^{1} \cdot$ Lina Vosyliūtè $^{2} \cdot$ Stephanie Brenda Smialowski ${ }^{3}$ \\ Published online: 17 March 2021 \\ (C) Springer Nature B.V. 2021

\section{Correction to: European Journal on Criminal Policy and Research https://doi.org/10.1007/s10610-020-09465-0}

The original version of this article unfortunately contained a mistake. Three references were not included in the original publication. The three references that need including are as follows:

Vosyliūtè, L., \& C. Conte (2018). Crackdown on NGOs assisting refugees and other migrants, Discussion Brief, ReSOMA, July. http://www.resoma.eu/publications/discussion-briefcrackdown-ngos-assisting-refugees-and-other-migrants.

Vosyliūtè, L., \& C. Conte (2019a). Crackdown on NGOs assisting refugees and other migrants, Policy Options Brief, ReSOMA. http://www.resoma.eu/publications/policy-optionbrief-crackdown-ngos.

Vosyliūte, L., \& C. Conte (2019b), Final Synthetic report on Crackdown on NGOs assisting refugees and other migrants, ReSOMA, June. http://www.resoma.eu/node/194.

The original article has been corrected.

Publisher's Note Springer Nature remains neutral with regard to jurisdictional claims in published maps and institutional affiliations.

The online version of the original article can be found at https://oi.org/10.1007/s10610-020-09465-0

\section{Jennifer Allsopp}

Jennifer_allsopp@gse.harvard.edu

1 Immigration Initiative at Harvard, Harvard University Graduate School of Education, Cambridge, MA, USA

2 Centre for European Policy Studies (CEPS), Brussels, Belgium

3 Science Po, Paris, France 